\title{
The Effects of Hypoxia and Inflammation on Synaptic Signaling in the CNS
}

\author{
Gatambwa Mukandala, Ronan Tynan, Sinead Lanigan and John J. O'Connor* \\ UCD School of Biomolecular and Biomedical Science, UCD Conway Institute of Biomolecular and Biomedical \\ Research, Belfield, Dublin 4, Ireland; Gatambwa.mukandala@ucdconnect.ie (G.M.); \\ ronan.tynan@ucdconnect.ie (R.T.); sinead.lanigan@ucdconnect.ie (S.L.) \\ * Correspondence: john.oconnor@ucd.ie; Tel.: +353-1-716-6765
}

Academic Editor: Donna Gruol

Received: 17 December 2015; Accepted: 2 February 2016; Published: 17 February 2016

\begin{abstract}
Normal brain function is highly dependent on oxygen and nutrient supply and when the demand for oxygen exceeds its supply, hypoxia is induced. Acute episodes of hypoxia may cause a depression in synaptic activity in many brain regions, whilst prolonged exposure to hypoxia leads to neuronal cell loss and death. Acute inadequate oxygen supply may cause anaerobic metabolism and increased respiration in an attempt to increase oxygen intake whilst chronic hypoxia may give rise to angiogenesis and erythropoiesis in order to promote oxygen delivery to peripheral tissues. The effects of hypoxia on neuronal tissue are exacerbated by the release of many inflammatory agents from glia and neuronal cells. Cytokines, such as TNF- $\alpha$, and IL-1 $\beta$ are known to be released during the early stages of hypoxia, causing either local or systemic inflammation, which can result in cell death. Another growing body of evidence suggests that inflammation can result in neuroprotection, such as preconditioning to cerebral ischemia, causing ischemic tolerance. In the following review we discuss the effects of acute and chronic hypoxia and the release of pro-inflammatory cytokines on synaptic transmission and plasticity in the central nervous system. Specifically we discuss the effects of the pro-inflammatory agent TNF- $\alpha$ during a hypoxic event.
\end{abstract}

Keywords: hypoxia; TNF- $\alpha$; adenosine; HIF- $1 \alpha$; hippocampus; long-term potentiation; prolyl hydroxylase inhibitor

\section{Introduction}

In the central nervous system, hypoxia occurs when there is an inadequate supply of oxygen to neuronal tissue. During acute hypoxia multiple oxygen sensors are deployed allowing neurons to adapt to the response. These responses to hypoxia include synaptic signaling decreases usually as a result of anerobic metabolism changes whilst chronic hypoxia may give rise to more severe perturbations of synaptic transmission and the activation of transcription factors that regulate oxygen homoestasis [1]. Different neurons adapt to a decreased oxygen supply to the brain in many ways, reflecting the diverse role of neuronal functions and also the extent of the hypoxia experienced. It is now known that an hypoxic event in brain tissue can cause ATP to drop by as much as $90 \%$ in less than $5 \mathrm{~min}$. Additionally, oxygen-sensitive ion channals including $\mathrm{Na}^{+}$and $\mathrm{K}^{+}$are activated bringing about changes in excitation and inhibition of neuronal and glial cells [2]. Depolarisation of cells may also take place causing the uptake of $\mathrm{Na}^{+}$and $\mathrm{Cl}^{-}$into cells followed by passive influx of water, resulting in swelling and oedema [2]. Hypoxic insults may also activate voltage-gated $\mathrm{Ca}^{2+}$ and $\mathrm{K}^{+}$ion channels and glutamate transporters, eventually causing excess glutamate to spill into the synaptic regions causing excitotoxicity. On the other hand, many of the long-term hypoxic responses are mediated by hypoxia inducible factors (HIF), such as HIF- $1 \alpha[3,4]$. HIF- $1 \alpha$ is a universally expressed transcriptional 
mediator of the hypoxic response that is degraded in an oxygen-dependent manner. Under normoxic conditions, HIF-1 $\alpha$ has a half-life of approximately 8 min due to hydroxylation by prolyl hydroxyl domains (PHDs) [5]. These PHDs exist in three different isoforms, PHD1, PHD2, and PHD3 and all require oxygen, iron, ascorbate and 2-oxoglutarate, a product of the oxygen dependent Kreb cycle, to hydroxylate HIF-1 $\alpha$. Under hypoxic conditions the Kreb cycle is inhbited leading to a reduction in 2-oxoglutarate, preventing the binding of PHDs to the targeting proline domains [4,6]. During hypoxia, the HIF-1 $\alpha$ protein stabilizes allowing it to recruit transcriptional co-activators, which are blocked during normal conditions via factor inhibiting HIF (FIH) [7]. This complex then permits for the transcription of hypoxia-related proteins through binding of the hypoxic responsive element (HRE). HRE binding induces the expression of genes, such as erythropoietin, vascular endothelial growth factor and insulin growth factor. These all play a neuroprotetive role in response to the hypoxic insult.

These acute and chronic responses to hypoxia are clearly manifested during ischemic events in the brain. An example of one such event with a hypoxic component is stroke, which is caused by a reduction in blood flow as a result of an obstruction or rupture of blood vessels within the brain and may cause both acute and chronic episodes of hypoxia. This leads to complex pathological changes taking place, which may lead to tissue necrosis through increased inflammation and oxygen deprivation [8]. During an ischemic stroke the eventual restriction of oxygen in the brain due to an obstruction leads to a cascade of events including hypoxia, increased expression of pro-inflammatory cytokines like tumor necrosis factor alpha (TNF- $\alpha)$ and interleukin-1beta (IL-1 $\beta$ ), as well as increased release of the excitatory neurotransmitter glutamate [9]. In this review we will discuss how hypoxia and the release of pro-inflammatory cytokines can effect synaptic transmission and plasticity in the central nervous system (CNS).

\section{Hypoxia and Synaptic Signaling}

Synaptic transmission in the CNS requires approximately $30 \%$ to $50 \%$ of cerebral oxygen. Therefore many of the changes in the CNS related to acute hypoxia stem from modifications of synaptic excitation and depression. The responses to hypoxia, which occur within seconds, most likely do not involve a role for HIF-1 $\alpha$ stabilization. Additionally, upon re-oxygenation after a short period, synaptic transmission can recover to $100 \%$ in many brain regions [10]. This decrease in synaptic signaling during acute hypoxia is thought to protect some neurons during ischemic events. Adenosine is one of many neurotransmitters, which plays a vital role in the neuroprotective response to hypoxia [11]. Adenosine $A_{1}$ receptors $\left(A_{1} R s\right)$, in particular, play a part in altering neurotransmitter release [12] and have wide expression levels throughout the CNS [13]. This inhibitory neuromodulation by $A_{1}$ Rs is coupled to inhibitory $G_{i}$ or $G_{0}$ containing $G$-proteins [14]. Activation of the receptor stimulates adenylyl cyclase, activates inwardly rectifying $\mathrm{K}^{+}$channels, thus inhibiting $\mathrm{Ca}^{2+}$ channels and activation of phospholipase $C$. This inhibits the release of a number of neurotransmitters including glutamate, dopamine, serotonin and acetylcholine thus making it the primary neuroprotective receptor. Adenosine forms through the enzymatic catabolism of adenosine triphosphate (ATP) into adenosine monophosphate (AMP), which then is broken down by ecto'5 nucelotidases into adenosine (see Figure 1). Adenosine kinase is mainly responsible for the removal of adenosine via phosphorylation to AMP [15]. Under hypoxic conditions when there is a build-up of adenosine in the extracellular space, hypoxia induced factors such as HIF- $1 \alpha$ also cause an increase in the ecto' 5 nucelotidases CD73, allowing for a breakdown of extracellular ATP into adenosine [16,17].

It is now known that during hypoxia, HIF-1 $\alpha$ inhibits the equilibrative nucleoside transporters ent- $1 / 2$ located on the membranes of neurons and glia preventing adenosine reuptake into the neuronal cell [18]. Extracellular adenosine binds to $\mathrm{A}_{1} \mathrm{Rs}$ located on both the postsynaptic and presynaptic membranes. Postsynaptic $\mathrm{A}_{1} \mathrm{R}$ activation inhibits the activation of glutamatergic $N$-methyl-D-aspartate receptors (NMDARs) and adenosine binding to $\mathrm{A}_{1}$ Rs located presynaptically [14]. Inhibition of neurotransmitter release can be suppressed by the addition of an $A_{1} R$ selective inhibitor, such as 8-cyclopentyl-1,3-dipropylxanthine (DPCPX), suggesting that adenosine binding is necessary for the 
reduction of post synaptic potentials [19]. It has also been shown that the $A_{1} R$ binding of adenosine inhibits NMDA receptor activation [20]. Creation of knockout mice with the deletion of presynaptic $\mathrm{A}_{1} \mathrm{Rs}$, uncovered the neuroprotective role that adenosine receptor binding plays in the hypoxic response [21]. Synaptic depression of the excitatory post-synaptic potential (EPSP) was attenuated allowing activation of glutamatergic NMDA receptors and increasing the likelihood for excitotoxicity. More importantly decreased extracellular levels of adenosine have been shown to lead to a loss of hypoxia-induced neuroprotection after repeated exposure to hypoxia [22].

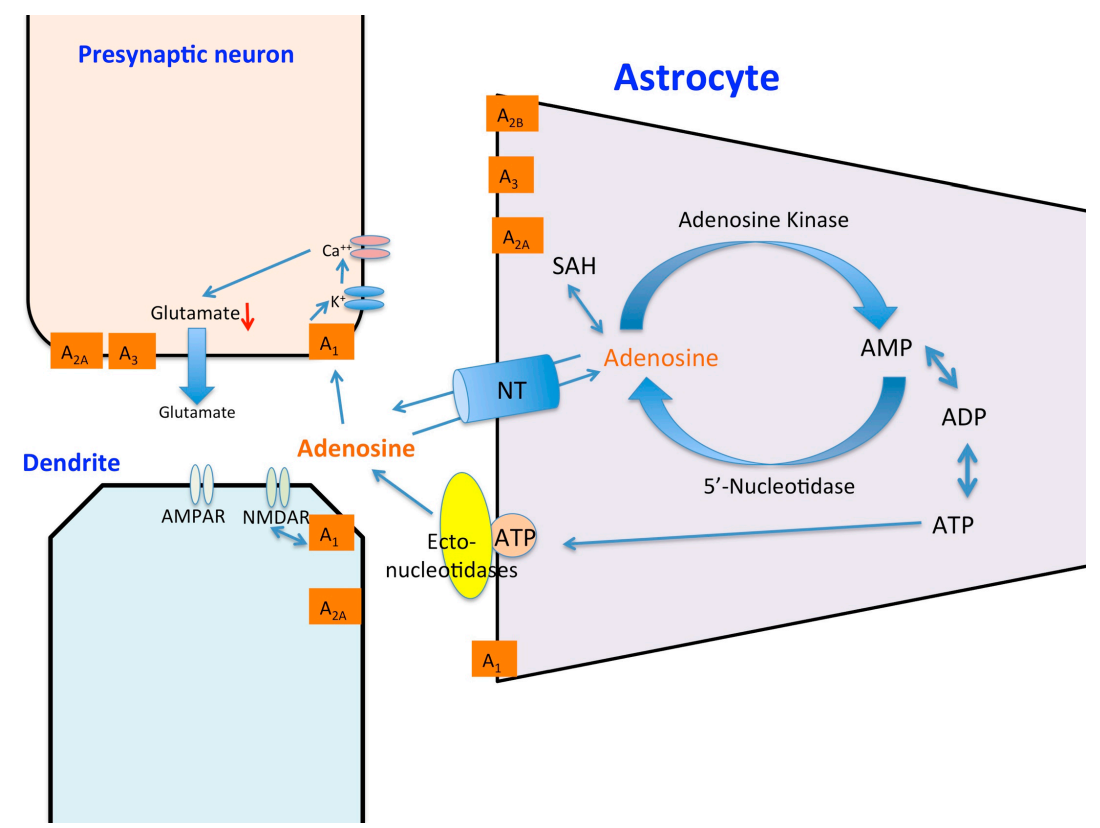

Figure 1. The effects of hypoxia on adenosine release in the CNS. Hypoxia causes a breakdown of extracellular ATP and AMP along with activation of membrane-bound transporters such as ectonucleotidases, leading to a build-up of extracellular adenosine. Adenosine binds presynaptically to $A_{1}$ Rs attenuating voltage dependent calcium channel (VDCC) function and thus neurotransmitter release and also binds postsynaptically to $A_{1}$ Rs receptors inactivating glutamatergic NMDARs. Adenosine is released from astrocytes in response to chronic hypoxia.

The depression of synaptic transmission in longer term hypoxia goes beyond a neuroprotective role. For example during longer duration hypoxia, nicotinamide adenine dinucleotide phosphate-oxidase oxidase production of reactive oxygen species (ROS) such as superoxides by microglial complement receptor 3 can activate protein phosphatase $2 \mathrm{~A}$ (PP2A), which causes the internalization of postsynaptic $\alpha$-amino-3-hydroxy-5-methyl-4-isoxazolepropionic acid receptors (AMPARs) through serine-threonine dephosphorlation [23]. This is similar to the discovery that the oxygen sensing C-elegans protein egl-9, which regulates HIF in an oxygen-dependent manner can also regulate C. elegans glutamate receptor-1 (GLR-1) trafficking through the generation of isoform-specific transgenes which interact with the GLR-1 promoter [24,25]. In normoxic conditions, egl-9 binds to Lin-10 preventing its phosphorylation, this complex then allows for the movement of glutamate receptors to the synapse. Under hypoxic conditions, Lin-10 is phosphorylated, thus preventing the formation of the EGL9/Lin-10 complex leading to a lack of synaptic GluR1 receptors [26].

One particular form of hypoxia, chronic intermittent hypoxia $(\mathrm{CIH})$ may have specific detrimental effects on CNS function. CIH can lead to the over-activation of NMDARs, leading to an overload of intracellular $\mathrm{Ca}^{2+}$ and a dephosphorylation of extracellular signal-regulated kinases (ERK) [27]. The CA1 region of the hippocampus is thought to be selectively vulnerable to $\mathrm{CIH}$ damage due to the high density of glutamate receptors located on its pyramidal neurons [28]. CIH also leads 
to a reduction in the levels of the transcription factor cAMP response element-binding protein (CREB) in its phosphorylated form [29]. This reduction in activated CREB leads to a lowering of CREB transcriptional targets, such as brain-derived neurotrophic factor (BDNF), causing cognitive dysfunction [30]. The $\mathrm{CIH}$-induced cognitive dysfunction was shown to be repaired through exogenous application of BDNF to the hypoxic cell [30]. Perinatal hypoxic events may also lead to increases in excitability in hippocampal regions. These events usually occur after asphyxia events just after birth and can lead to long term synaptic changes. Changes in excitability in some local brain regions such as the CA1 region have also been noted [31]. The pursuant neonatal seizures may be related to the phosphorylation of the AMPA GLUA1 receptors on serine 183 and serine 845. This may enhance AMPA receptor excitatory post synaptic currents (EPSCs) which allows for a decrease in the percentage of silent synapses and an increase in AMPA receptor function [32]. This loss of silent synapses is thought to be the mechanism, which attenuates synaptic plasticity in adult life [33]. In critical cases of hypoxia-re-oxygenation the brain loses the ability to form new memories. This anterograde amnesia is decoupled from the hippocampus and its primarily caused by adenosine up-regulation of caspase 1 and then IL-1 $\beta$ in the amygdala [34]. These effects were shown to last up to five hours after re-oxygenation with caspase inhibitors, such as YVAD-CMK, able to shorten the recovery time [34]. The links of hypoxia to cognitive disorders, as well as ability to cause neuronal apoptosis through hyper-excitability, displays the importance of understanding hypoxia and preventing its long-term effects.

\section{Hypoxia and Synaptic Plasticity}

As previously mentioned, hippocampal neuron exposure to hypoxia may lead to cognitive deficits due to synaptic plasticity impairments [35]. Many studies have investigated the relationship between oxygen deprivation and synaptic plasticity. Early studies indicated that brief periods of hypoxia could disrupt long-term potentiation (LTP) in the CA1 hippocampus and that this effect could be reproduced with brief application of adenosine prior to the induction of LTP [36-38]. It was later discovered that a brief anoxic episode, as opposed to hypoxia, applied to brain slices, could generate a new type of LTP although still voltage-, NMDA- [39], protein kinase C (PKC)- and NO-dependent [40-42]. It is proposed that it is the re-oxygenation and not initial de-oxygenation of neurons and the subsequent high concentration of glutamate that in fact causes the excessive activation of NMDARs and subsequent large influx of $\mathrm{Ca}^{2+}$ [43]. It has also been shown that chemically-induced hypoxia with the use of PHD inhibitors, and thus hypoxia mimetics, whilst having no effect on synaptic signaling at low concentrations per se, could inhibit LTP in the hippocampus [44,45]. Application of the iron chelator deferoxamine mesylate (DFO) or dimethyloxaloglycine (DMOG), both non-specific pharmacological inhibitors of PHD, and thus increasers of HIF-1 $\alpha$ expression [46] could impair LTP in the CA1 hippocampus $[4,44,45,47]$. Interestingly the application of DMOG to the dentate gyrus region of hippocampal slices did not impair LTP [29]. It is believed that these effects of PHD inhibitors are not HIF-dependent. There is also increasing evidence for a role for $\mathrm{CIH}$ in synaptic plasticity and specifically LTP. Initial reports in early 2000 demonstrated that CIH treated animals demonstrated impaired LTP in isolated rat hippocampal slices [48,49]. More recently two reports have put forward evidence for a role for BDNF in this impairment $[30,50]$. They found that application of BDNF reversed the IH-induced impairment of LTP. In our own laboratories we have implicated a role for PHDs in this inhibition of LTP by intermittent hypoxia [29].

\section{Hypoxia and Neuroinflammation in the CNS}

During an ischemic stroke and resulting hypoxia, inflammatory cytokines are released by microglia, neurons and astrocytes with glutamate largely released by neurons. The up-regulation of pro-inflammatory cytokines through the activation of microglia and astrocytes in the brain contribute a great deal to ischemic brain damage [51]. During hypoxia, HIF- $1 \alpha$ binds to HRE like binding sites allowing for the up-regulation of cytokines, such as IL- $\beta$, IL-6, IL-8, and TNF- $\alpha$. Mutations in either the HIF- $1 \alpha$ gene or its binding site at the promoter inhibit this cytokine up-regulation [46]. 
Up-regulation of IL- $1 \beta$ is related to hypoxic hyperexcitability due to the fact that IL- $1 \beta$ can activate tyrosine kinases, which then phosphorylate the NMDAR subunits, NR2A and NR2. This increase in NMDAR potentiation leads to excessive flow of $\mathrm{Ca}^{2+}$ leading to hyperexcitability and neuronal injury [52]. Hypoxia also leads to activation of nuclear factor $\mathrm{KB}(\mathrm{NF} \mathrm{KB})$ signaling pathways whereby HIF- $1 \alpha$ has a molecular interaction with the inflammatory mediator NFKB. HRE binding, as seen in Figure 2, allows for the expression of $\mathrm{NF} \kappa \mathrm{B}$, which then activates the transcription of inflammatory genes and HIF proteins [53]. NFkB expression is increased when hypoxia is followed by a period of re-oxygenation [54]. Reactive oxygen species (ROS) have been shown to both activate and inactivate $\mathrm{NFKB}$, which could explain the importance of the re-oxygenation period. ROS can trigger both apoptotic and necrotic cell death depending on the severity of the oxidative stress [55-57]. Another form of hypoxia, $\mathrm{CIH}$, such as seen in sleep apnea can lead to neuronal cell death and one of the mechanisms involved may be inflammation. Neural inflammation caused by $\mathrm{CIH}$ can be region specific with the expression of microglial toll-like receptor-4 (TLR4) increased differentially across areas of the CNS [58]. Hypoxia-re-oxygenation increases microglial levels of inducible nitric oxide synthase (iNOS) leading to neuronal cell loss through apoptosis and memory impairment [59] Many other insults such as bacterial, viral, cytokines and neurodegenerative insults induce iNOS in microglia [60]. This increase in iNOS raises the levels of NO allowing for the inhibition of neuronal respiration causing glutamate release [61]. Rho-associated protein kinase (ROCK) is thought to play a vital role in this pathway as the introduction of the ROCK inhibitor, fasudil, attenuates the neuronal apoptosis [62]. Thus inflammatory pathways and microglial activation are key components to the hypoxic response whereby their activation allows for formation of ROS as well as having the ability to modulate glutamatergic receptors. The important role they play in causing neuronal cell damage as well their potential to be neuroprotective through hypoxic preconditioning makes the inflammatory response a vital therapeutic target in hypoxia. Only recently has it been reported that patients with obstructive sleep apnea (involving episodes of $\mathrm{IH}$ ) were 1.37 times more likely to have Parkinson's disease than patients without the disease [63].

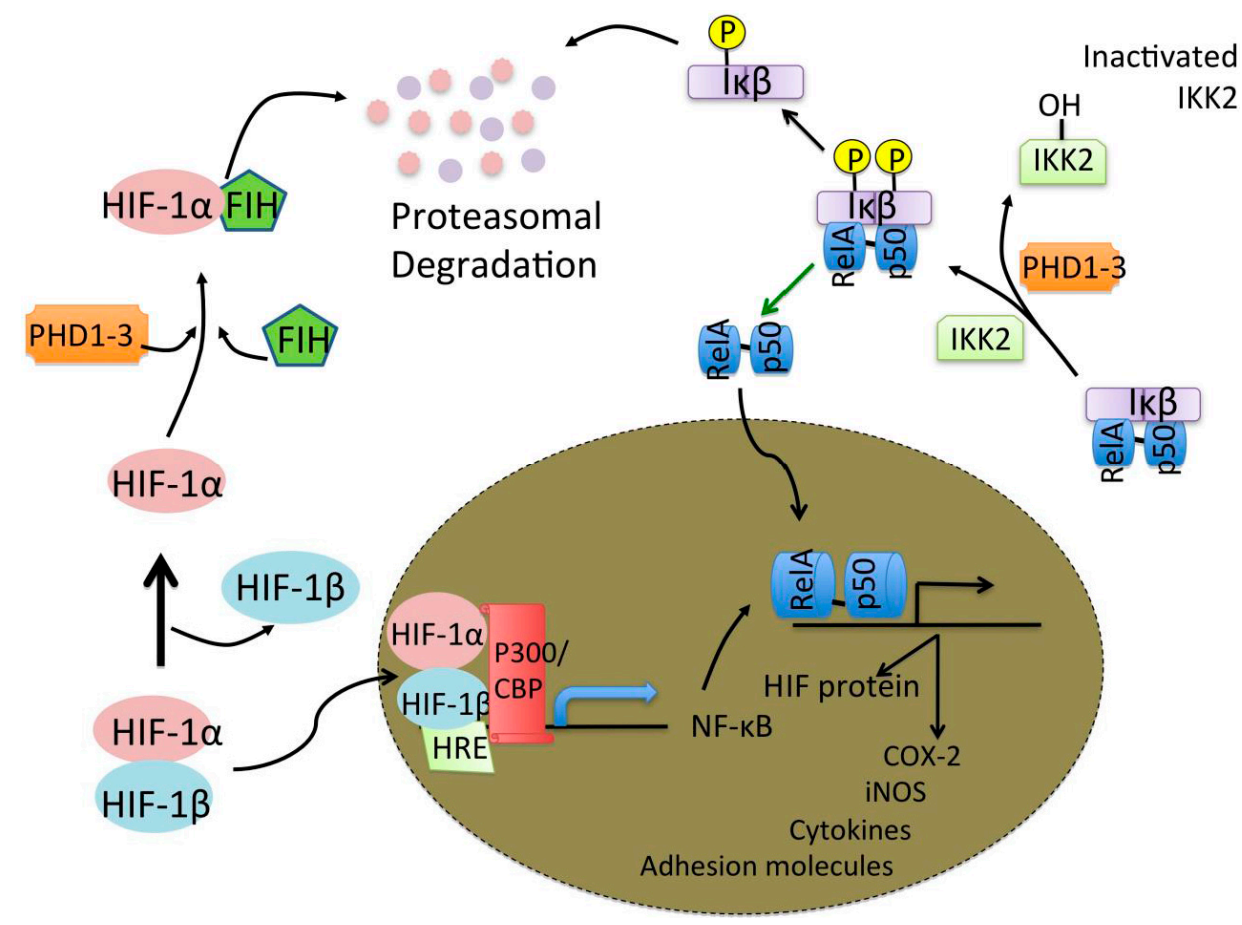

Figure 2. Hypoxia and NFKB activation. During hypoxic HIF-1 $\alpha$ binding to the HRE induces the expression of NFKB (left). NFKB p50 p65 dimer is able to freely activate the transcription of inflammatory and HIF proteins (right). 


\section{TNF- $\alpha$ and Hypoxia}

TNF- $\alpha$, a pro-inflammatory cytokine produced primarily by monocytes and macrophages in the periphery and microglia and neurons in the CNS, is involved in the promotion of the inflammatory response and cognitive dysfunction [64,65]. TNF- $\alpha$ is initially produced as a 212-amino acid-long type II transmembrane that is stable as a homotrimer. The cleavage of the membrane-integrated form by TNF- $\alpha$ converting enzyme produces a soluble homotrimer, which binds to either of two receptors, TNF receptor type 1 (TNFR1) or TNF receptor type 2 (TNFR2). TNFR1 is constitutively expressed throughout most tissues and is thought to be the main TNF signaling receptor. The activation of TNF-R1 leads to either apoptotic cell death or the activation of either the caspase-8 pathway or c-Jun NH2-terminal kinase (JNK) pathways, or neuroprotection through the binding of IkB kinase (IKK) complex and the subsequent activation of the NFkB pathway [66]. The signaling network in TNF-R1 is interesting due to the extensive crosstalk between the NFKB, and JNK signaling pathways. The cells susceptibility to apoptosis increases in the absence of NFKB. The activation of TNFR2 leads to the activation of the NFKB pathway, phosphatidyl-inositol-3 kinase (PI3K) and subsequent transcription of neuroprotective mediators like calbindin and manganese superoxide dismutase $[67,68]$. Specifically in microglia activation of TNFR2 anti-inflammatory pathways may be induced [69]. A putative role for TNF- $\alpha$ has been shown in rats infused with lipopolysaccharide (LPS may promote the secretion of pro-inflammatory cytokines including TNF- $\alpha$ and IL-1 $\beta$ ) into the fourth ventricle to induce chronic neuroinflammation [70]. TNF- $\alpha$ synthesis inhibition was found to restore the neuronal function as well as reverse cognitive deficits induced by the chronic neuroinflammation [70].

It is becoming apparent that TNF- $\alpha$ is one of the most important inflammatory cytokines to be studied in relation to neuronal damage caused by the absence of oxygen due to the fact that it actively participates in the immune-mediated inflammation of stroke and other neurodegenerative diseases with an hypoxia component [71]. The release of TNF- $\alpha$ is a result of the pathogenesis of disorders such as stroke [72], Alzheimer's disease [73], Parkinson's disease [74] and severe infections such as meningitis [75], yet its role during hypoxia is not fully understood. In severe ischemia TNF- $\alpha$ levels appear to be elevated in affected brain tissue after $24 \mathrm{~h}$ [76]. One such critical role in neuroinflammation has been illustrated whereby TNF- $\alpha$ can damage dopaminergic neurons and thus anti-TNF agents may ameliorate Parkinson's disease [74]. Despite many research papers in this field few laboratories have investigated the effects of acute hypoxia and inflammatory mediators on synaptic transmission $[77,78]$. Recently our laboratory reported that recovery of synaptic transmission in CA1 neurons was impaired post-hypoxia in the presence of TNF- $\alpha$ [77]. It also been shown that HIF-1 $\alpha$ has a binding site for the Fas Associated Death Domain promoter, which is an adapter molecule in TNFR1 mediated cell death. Therefore it has a direct role in TNF- $\alpha$ mediated apoptosis which may help explain the poor recovery of EPSPs following a hypoxic insult [79].

A growing body of evidence indicates that TNF- $\alpha$ may play a role in the regulation of tolerance to chronic hypoxia such as occurs in ischemia yet it has a deleterious effect in ischemic brain injury after stroke [80]. It seems that administration of a high dose of lipopolysaccharide (LPS) may induce a robust inflammatory response that can result in lethal septic shock whereas administration of a low dose of LPS may induce a protective state of tolerance to subsequent exposure to LPS at doses that might cause serious injury [81,82]. In fact LPS preconditioning is known to exert neuroprotection from cerebral ischemia $[83,84]$. In cerebellar granule neurons the neuroprotective effects of LPS preconditioning were said to be independent of endogenous IL- $1 \beta$ but dependent on endogenous TNF- $\alpha$ and also IL-6 [85]. Our laboratories have recently provided evidence that TNF- $\alpha$ has a preconditioning effect following a glutamate toxic insult $24 \mathrm{~h}$ later in the CA1 region of rat organotypic slices [65]. We suggested that the preconditioning effects may be as a result of changing resting $\mathrm{Ca}^{2+}$ levels and $\mathrm{Ca}^{2+}$ influx in the presence of TNF- $\alpha$. 


\section{TNF- $\alpha$ and Synaptic Plasticity}

A growing body of evidence has highlighted the role of TNF- $\alpha$ in glutamatergic synaptic plasticity and scaling. It has been shown that TNF- $\alpha$ has an inhibitory effect on LTP in both the CA1 and dentate gyrus [76,86-89]. Studies initially carried out by Tancredi et al. (1992) [90] showed an inhibitory effect of TNF- $\alpha$ on LTP induction in the CA1 region, which was concentration-dependent. However, they demonstrated that short-term application of TNF- $\alpha(>50 \mathrm{~min})$ did not affect LTP. These findings and others highlight the various parameters involved in the regulatory role that this cytokine plays in synaptic plasticity. The inhibitory actions of TNF- $\alpha$ on LTP have been shown to be mediated through the signaling pathways, P38 MAP kinase and JNK [91]. Butler et al. (2004) [88] reported that the inhibition of LTP by TNF- $\alpha$ was in fact a biphasic response. SB203580, a P38 MAPK inhibitor, blocked the early inhibition of LTP by TNF- $\alpha$ but did not reverse its late inhibition ( $3 \mathrm{~h}$ following induction), possibly due to the requirement for new protein synthesis. Using antagonists for metabotropic glutamate receptor 5 (mGluR5) and ryanodine, a potential role for metabotropic glutamate receptors and ryanodine sensitive intracellular $\mathrm{Ca}^{2+}$ stores in TNF- $\alpha$ mediated inhibition of LTP have also been proposed [87].

Other studies have provided evidence that exogenous application of TNF- $\alpha$ whilst not inhibiting LTP in the CA1 region of the hippocampus may alter homeostatic plasticity (synaptic scaling) rather than synaptic plasticity [92]. These studies have shown that glia released TNF- $\alpha$ is required for synaptic scaling through AMPAR trafficking to the membrane [92-94]. Others have reported that the increase in AMPAR expression on the cell surface is mediated through the P13 kinase pathway and the AMPARs trafficked were lacking the GLR-2 subunit. Since LTP is dependent on synaptic glutamate it is also interesting to note that TNF- $\alpha$ has been shown to increase glutamate release from astrocytes [95], block glutamate transporters [96], and also may have a modulatory effect on the expression of GLT-1 and GLT-2. These effects combined may result in increased glutamate concentrations in the synaptic cleft $[97,98]$. TNFR1, but not TNFR2, may play an important role in AMPAR localization on the membrane of cortical neurons. Deletion of TNFR1 resulted in a decrease of AMPAR clustering on the synaptic membrane, which was not rescued by exogenous application of TNF- $\alpha$ [99]. These observations indicate a potential therapeutic approach for TNF- $\alpha$ via TNFR1 in mediating AMPAR excitotoxicity. Glutamatergic gliotransmission is an important stimulatory input to excitatory synapses and it has been shown that TNF- $\alpha$ is a modulator of this process in the dentate gyrus [100]. Many of the discrepancies observed with regard to the effects of TNF- $\alpha$ on LTP may be region specific or indeed depend on the induction protocol used to induce LTP. There are many factors regulating the magnitude of LTP induced by different parameters such as high frequency stimulation and theta burst stimulation [101] (Figure 3). Recently, we have shown that the stimulation parameters used to induce LTP may have an influence on TNF- $\alpha$ 's ability to inhibit LTP [102]. TNF- $\alpha$ has no inhibitory effect on LTP when induced with prolonged high frequency stimulation (HFS) whereas full inhibition was observed when LTP was induced by theta burst stimulation (TBS). Figure 3 illustrates a potential mechanism that might explain this discrepancy whereby TBS may trigger alternative signaling cascades to HFS that can be modulated by TNF- $\alpha$.

\section{TNF- $\alpha$, Hypoxia and Synaptic Plasticity}

Hippocampal slices exposed to acute hypoxia may recover when oxygen is re-introduced. Recently it has been shown that in the presence of TNF- $\alpha$ there is an impairment in the recovery of synaptic transmission in the CA1 region post-hypoxia [77]. Conversely, hypoxia has also been shown to increase intercellular $\mathrm{Ca}^{2+}$ levels and activate calmodulin-dependent protein kinase II (CaMKII) through a TNF- $\alpha$ independent mechanism [103]. However CaMKII is also capable of activating the PI3K-PKC $\lambda$-AMPAR signaling pathway. TNF- $\alpha$ has been found to play roles in cell adhesion up-regulation, disruption of the blood brain barrier and is a key component for the participation of glial cells in the physiological control of synaptic transmission and plasticity through the release of glutamate, a process known as glutamatergic gliotranmission $[100,104]$. TNF- $\alpha$ has been shown to 
increase the release of glutamate from astrocytes, maintain glutamate levels through the blocking of glutamate transporters [96] and modulate the expression of Glut-1 and Glut-2. All these effects by $\mathrm{TNF}-\alpha$ result in the increase in the concentration of glutamate in the synaptic cleft, which may have an influence on the magnitude of LTP post-hypoxia. Using a robust LTP-inducing stimulus protocol we have been able to demonstrate a significant enhancing effect of TNF- $\alpha$ on LTP post hypoxia but only in the dentate gyrus of the hippocampus [102]. In the presence of DMOG (a non-specific PHD inhibitor) this enhancement of LTP was still evident perhaps indicating a novel HIF/PHD-independent effect of TNF- $\alpha$ [102].

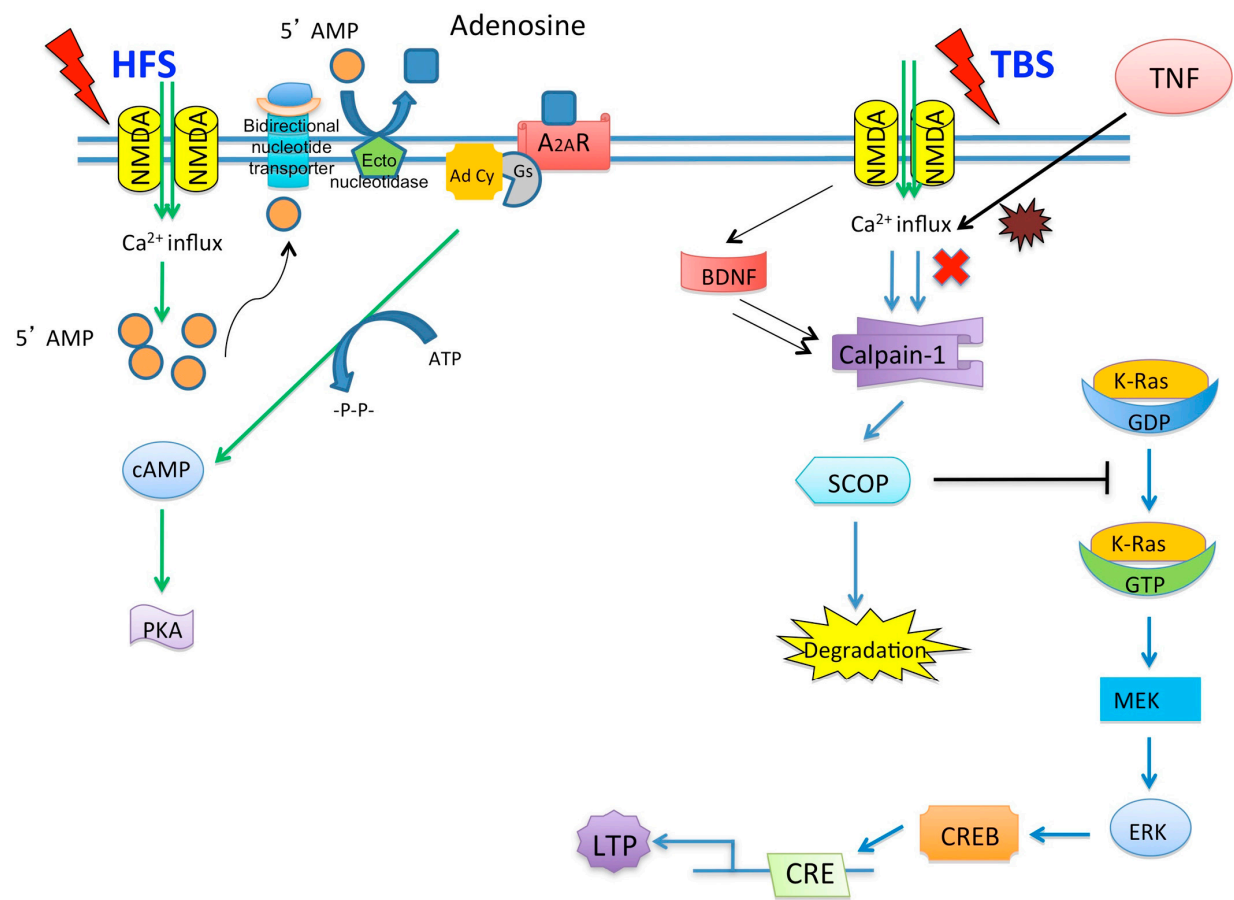

Figure 3. Putative signaling pathways activated after HFS- and TBS-induced LTP. HFS-induced LTP may be dependent on the breakdown of $5^{\prime}$ AMP into adenosine. Adenosine activates the $A_{2 A} R$ receptor leading to cAMP and PKA activation. TBS-induced LTP involves the influx of $\mathrm{Ca}^{2+}$ and subsequent activation of calpain-1. The activation of calpain-1 leads to a calapin-1-mediated suprachiasmatic nucleus circadian oscillatory protein degradation and ERK activation. Exogenous TNF- $\alpha$ inhibits LTP induced by TBS only. During hypoxia, TNF- $\alpha$ may have potentiating effect on HFS-induced LTP but not TBS.

\section{Conclusions}

Hypoxia is one of the key components, which can arise from neuropathological conditions such as stroke, Parkinson's or Alzheimer's disease. Hypoxic events can cause the release of pro-inflammatory cytokines from neurons and glial cells, such as TNF- $\alpha$, which can lead to further neurotoxicity or indeed neuroprotection in the brain. However, the effects of TNF- $\alpha$ on neurons during de- and re-oxygenation of neurons is largely unknown. Many studies have now shown that pro-inflammatory cytokines, such as TNF- $\alpha$, play a key role in the regulation of synaptic transmission and plasticity in the absence and presence of acute hypoxia, especially within the hippocampus. The mechanisms by which elevated levels of TNF- $\alpha$ have an enhancing or detrimental effect on synaptic signaling and synaptic plasticity in the presence or after a hypoxic event remains to be elucidated.

Acknowledgments: We would like to thank Irish Aid and University College Dublin for financial support.

Author Contributions: Gatambwa Mukandala wrote the sections on TNF- and hypoxia and hypoxia and neuroinflammation in the CNS and conceived and designed experiments referred to in the review. Ronan Tynan 
wrote the sections on hypoxia and synaptic signaling and hypoxia and synaptic plasticity. Sinead Lanigan wrote the introduction and edited the final version of the manuscript and figures. John J. O'Connor conceived and designed the experiments referred to in the review, contributed reagents/materials/analysis tools and wrote the paper.

Conflicts of Interest: The authors declare no conflict of interest.

\section{Abbreviations}

$\begin{array}{ll}\text { A }_{1} \text { Rs } & \text { Adenosine } \mathrm{A}_{1} \text { receptors } \\ \text { AMP } & \text { adenosine monophosphate } \\ \text { AMPARs } & \alpha \text {-amino-3-hydroxy-5-methyl-4-isoxazolepropionic acid receptors } \\ \text { ATP } & \text { adenosine triphosphate } \\ \text { BDNF } & \text { brain-derived neurotrophic factor } \\ \text { CaMKII } & \text { calmodulin-dependent protein kinase II } \\ \text { CIH } & \text { chronic intermittent hypoxia } \\ \text { CNS } & \text { central nervous system } \\ \text { CREB } & \text { cAMP response element-binding protein } \\ \text { DMOG } & \text { dimethyloxaloglycine } \\ \text { DPCPX } & \text { 8-cyclopentyl-1,3-dipropylxanthine } \\ \text { EPSP } & \text { excitatory post-synaptic potential } \\ \text { ERK } & \text { extracellular signal-regulated kinases } \\ \text { HIF } & \text { hypoxia inducible factors } \\ \text { HRE } & \text { hypoxic responsive element } \\ \text { IL-1 } \beta & \text { interleukin-1beta } \\ \text { iNOS } & \text { inducible nitric oxide synthase } \\ \text { LPS } & \text { lipopolysaccharide } \\ \text { LTP } & \text { long-term potentiation } \\ \text { NFkB } & \text { nuclear factor kB } \\ \text { NMDAR } & \text { N-methyl-D-aspartate receptors } \\ \text { PHDs } & \text { prolyl hydroxyl domains } \\ \text { PI3K } & \text { phosphatidyl-inositol-3 kinase } \\ \text { ROCK } & \text { tumor necrosis factor alpha } \\ \text { ROS } & \text { TNF- } \alpha\end{array}$

\section{References}

1. Sharp, F.R.; Bernaudin, M. HIF1 and oxygen sensing in the brain. Nat. Rev. Neurosci. 2004, 5, 437-448. [CrossRef] [PubMed]

2. Bickler, P.E.; Donohoe, P.H. Adaptive responses of vertebrate neurons to hypoxia. J. Exp. Biol. 2002, 205, 3579-3586.

3. Eltzschig, H.K.; Bratton, D.L.; Colgan, S.P. Targeting hypoxia signaling for the treatment of ischaemic and inflammatory diseases. Nat. Rev. Drug Discov. 2014, 13, 852-869. [CrossRef] [PubMed]

4. Corcoran, A.; O'Connor, J.J. Hypoxia-inducible factor signaling mechanisms in the central nervous system. Acta Physiol. 2013, 208, 298-310. [CrossRef] [PubMed]

5. Moroz, E.; Carlin, S.; Dyomina, K.; Burke, S.; Thaler, H.T.; Blasberg, R.; Serganova, I. Real-time imaging of HIF-1 $\alpha$ stabilization and degradation. PLoS ONE 2009, 4, e5077. [CrossRef] [PubMed]

6. Webb, J.D.; Coleman, M.L.; Pugh, C.W. Hypoxia, hypoxia-inducible factors (HIF), HIF hydroxylases and oxygen sensing. Cell. Mol. Life Sci. 2009, 66, 3539-3554. [CrossRef] [PubMed] 
7. Semenza, G.L. Oxygen sensing, hypoxia-inducible factors, and disease pathophysiology. Annu. Rev. Pathol. 2014, 9, 47-71. [CrossRef] [PubMed]

8. Kamel, H.; Iadecola, C. Brain-immune interactions and ischemic stroke: Clinical implications. Arch Neurol. 2012, 69, 576-581. [PubMed]

9. Amantea, D.; Micieli, G.; Tassorelli, C.; Cuartero, M.I.; Ballesteros, I.; Certo, M.; Moro, M.A.; Lizasoain, I.; Bagetta, G. Rational modulation of the innate immune system for neuroprotection in ischemic stroke. Front. Neurosci. 2015, 9, 147. [CrossRef] [PubMed]

10. Lipton, P.; Whittingham, T.S. The effect of hypoxia on evoked potentials in the in vitro hippocampus. J. Physiol. 1979, 287, 427-438. [CrossRef] [PubMed]

11. Björklund, O.; Shang, M.; Tonazzini, I.; Daré, E.; Fredholm, B.B. Adenosine A1 and A3 receptors protect astrocytes from hypoxic damage. Eur. J. Pharmacol. 2008, 596, 6-13. [CrossRef] [PubMed]

12. Palmer, T.M.; Stiles, G.L. Adenosine receptors. Neuropharmacology 1995, 34, 683-694. [CrossRef]

13. Reppert, S.M.; Weaver, D.R.; Stehle, J.H.; Rivkees, S.A. Molecular cloning and characterization of a rat A1-adenosine receptor that is widely expressed in brain and spinal cord. Mol. Endocrinol. 1991, 5, 1037-1048. [CrossRef] [PubMed]

14. McCool, B.A.; Farroni, J.S. A1 adenosine receptors inhibit multiple voltage-gated $\mathrm{Ca}^{2+}$ channel subtypes in acutely isolated rat basolateral amygdala neurons. Br. J. Pharmacol. 2001, 132, 879-888. [CrossRef] [PubMed]

15. Boison, D. Adenosine kinase, epilepsy and stroke: Mechanisms and therapies. Trends Pharmacol. Sci. 2006, 27, 652-658. [CrossRef] [PubMed]

16. Görlach, A. Control of adenosine transport by hypoxia. Circ. Res. 2005, 97, 1-3. [CrossRef] [PubMed]

17. Takahashi, T.; Otsuguro, K.; Ohta, T.; Ito, S. Adenosine and inosine release during hypoxia in the isolated spinal cord of neonatal rats. Br. J. Pharmacol. 2010, 161, 1806-1816. [CrossRef] [PubMed]

18. Morote-Garcia, J.C.; Rosenberger, P.; Nivillac, N.M.; Coe, I.R.; Eltzschig, H.K. Hypoxia-inducible factor-dependent repression of equilibrative nucleoside transporter 2 attenuates mucosal inflammation during intestinal hypoxia. Gastroenterology 2009, 136, 607-618. [CrossRef] [PubMed]

19. Choi, I.S.; Cho, J.H.; Lee, M.G.; Jang, I.S. Enzymatic conversion of ATP to adenosine contributes to ATP-induced inhibition of glutamate release in rat medullary dorsal horn neurons. Neuropharmacology 2015, 93, 94-102. [CrossRef] [PubMed]

20. De Mendonça, A.; Sebastião, A.M.; Ribeiro, J.A. Inhibition of NMDA receptor-mediated currents in isolated rat hippocampal neurones by adenosine A1 receptor activation. Neuroreport 1995, 6, 1097-1100. [CrossRef] [PubMed]

21. Arrigoni, E.; Crocker, A.J.; Saper, C.B.; Greene, R.W.; Scammell, T.E. Deletion of presynaptic adenosine A1 receptors impairs the recovery of synaptic transmission after hypoxia. Neuroscience 2005, 132, 575-580. [CrossRef] [PubMed]

22. Cui, M.; Bai, X.; Li, T.; Chen, F.; Dong, Q.; Zhao, Y.; Liu, X. Decreased extracellular adenosine levels lead to loss of hypoxia-induced neuroprotection after repeated episodes of exposure to hypoxia. PLOS ONE 2013, 8, e57065. [CrossRef] [PubMed]

23. Zhang, J.; Malik, A.; Choi, H.B.; Ko, R.W.; Dissing-Olesen, L.; MacVicar, B.A. Microglial CR3 activation triggers long-term synaptic depression in the hippocampus via NADPH oxidase. Neuron 2014, 82, 195-207. [CrossRef] [PubMed]

24. Ma, D.K.; Vozdek, R.; Bhatla, N.; Horvitz, H.R. CYSL-1 interacts with the $\mathrm{O}_{2}$-sensing hydroxylase EGL-9 to promote $\mathrm{H}_{2} \mathrm{~S}$-modulated hypoxia-induced behavioral plasticity in C. elegans. Neuron 2012, 73, 925-940. [CrossRef] [PubMed]

25. Park, E.C.; Ghose, P.; Shao, Z.; Ye, Q.; Kang, L.; Xu, X.Z.; Powell-Coffman, J.A.; Rongo, C. Hypoxia regulates glutamate receptor trafficking through an HIF-independent mechanism. EMBO J. 2012, 31, 1379-1393. [CrossRef] [PubMed]

26. Epstein, A.C.; Gleadle, J.M.; McNeill, L.A.; Hewitson, K.S.; O’Rourke, J.; Mole, D.R.; Mukherji, M.; Metzen, E.; Wilson, M.I.; Dhanda, A.; et al. C. elegans EGL-9 and mammalian homologs define a family of dioxygenases that regulate HIF by prolyl hydroxylation. Cell 2001, 107, 43-54. [CrossRef]

27. Wang, J.; Ming, H.; Chen, R.; Ju, J.M.; Peng, W.D.; Zhang, G.X.; Liu, C.F. CIH-induced neurocognitive impairments are associated with hippocampal $\mathrm{Ca}^{2+}$ overload, apoptosis, and dephosphorylation of ERK1/2 and CREB that are mediated by overactivation of NMDARs. Brain Res. 2015, 1625, 64-72. [CrossRef] [PubMed] 
28. McDonald, J.W.; Johnston, M.V. Physiological and pathophysiological roles of excitatory amino acids during central nervous system development. Brain Res. Brain Res. Rev. 1990, 15, 41-70. [CrossRef]

29. Wall, A.M.; Corcoran, A.E.; O'Halloran, K.D.; O'Connor, J.J. Effects of prolyl-hydroxylase inhibition and chronic intermittent hypoxia on synaptic transmission and plasticity in the rat CA1 and dentate gyrus. Neurobiol. Dis. 2014, 62, 8-17. [CrossRef] [PubMed]

30. Xie, H.; Leung, K.L.; Chen, L.; Chan, Y.S.; Ng, P.C.; Fok, T.F.; Wing, Y.K.; Ke, Y.; Li, A.M.; Yung, W.H. Brain-derived neurotrophic factor rescues and prevents chronic intermittent hypoxia-induced impairment of hippocampal long-term synaptic plasticity. Neurobiol. Dis. 2010, 40, 155-162. [CrossRef] [PubMed]

31. Jensen, F.E.; Wang, C.; Stafstrom, C.E.; Liu, Z.; Geary, C.; Stevens, M.C. Acute and chronic increases in excitability in rat hippocampal slices after perinatal hypoxia in vivo. J. Neurophysiol. 1998, 79, 73-81. [PubMed]

32. Zhou, C.; Lippman, J.J.; Sun, H.; Jensen, F.E. Hypoxia-induced neonatal seizures diminish silent synapses and long-term potentiation in hippocampal CA1 neurons. J. Neurosci. 2011, 31, 18211-18222. [CrossRef] [PubMed]

33. Kerchner, G.A.; Nicoll, R.A. Silent synapses and the emergence of a postsynaptic mechanism for LTP. Nat. Rev. Neurosci. 2008, 9, 813-825. [CrossRef] [PubMed]

34. Chiu, G.S.; Chatterjee, D.; Darmody, P.T.; Walsh, J.P.; Meling, D.D.; Johnson, R.W.; Freund, G.G. Hypoxia/reoxygenation impairs memory formation via adenosine-dependent activation of caspase 1. J. Neurosci. 2012, 32, 13945-13955. [CrossRef] [PubMed]

35. Row, B.W.; Liu, R.; Xu, W.; Kheirandish, L.; Gozal, D. Intermittent hypoxia is associated with oxidative stress and spatial learning deficits in the rat. Am. J. Respir. Crit. Care Med. 2003, 167, 1548-1553. [CrossRef] [PubMed]

36. Arai, A.; Kessler, M.; Lynch, G. The effects of adenosine on the development of long-term potentiation. Neurosci. Lett. 1990, 119, 41-44. [CrossRef]

37. Arai, A.; Vanderklish, P.; Kessler, M.; Lee, K.; Lynch, G. A brief period of hypoxia causes proteolysis of cytoskeletal proteins in hippocampal slices. Brain Res. 1990, 555, 276-280. [CrossRef]

38. Lyubkin, M.; Durand, D.M.; Haxhiu, M.A. Interaction between tetanus long-term potentiation and hypoxia-induced potentiation in the rat hippocampus. J. Neurophysiol. 1997, 78, 2475-2482. [PubMed]

39. Hammond, C.; Crépel, V.; Gozlan, H.; Ben-Ari, Y. Anoxic LTP sheds light on the multiple facets of NMDA receptors. Trends Neurosci. 1994, 17, 497-503. [CrossRef]

40. Hsu, K.S.; Huang, C.C. Characterization of the anoxia-induced long-term synaptic potentiation in area CA1 of the rat hippocampus. Br. J. Pharmacol. 1997, 122, 671-681. [CrossRef] [PubMed]

41. Huang, C.C.; Hsu, K.S. Nitric oxide signaling is required for the generation of anoxia-induced long-term potentiation in the hippocampus. Eur. J. Neurosci. 1997, 9, 2202-2206. [CrossRef] [PubMed]

42. Weilinger, N.L.; Tang, P.L.; Thompson, R.J. Anoxia-induced NMDA receptor activation opens pannexin channels via Src family kinases. J. Neurosci. 2012, 32, 12579-12588. [CrossRef] [PubMed]

43. Kass, I.S.; Lipton, T.P. Calcium and Long-term transmission damage following anoxia in dentate gyrus and CA1 regions of the rat hippocampal slice. J. Physiol. 1986, 378, 313-334. [CrossRef] [PubMed]

44. Muñoz, P.; Humeres, A.; Elgueta, C.; Kirkwood, A.; Hidalgo, C.; Núñez, M.T. Iron mediates $\mathrm{N}$-methyl-D-aspartate receptor-dependent stimulation of calcium-induced pathways and hippocampal synaptic plasticity. J. Biol. Chem. 2011, 286, 13382-13392. [CrossRef] [PubMed]

45. Corcoran, A.; Kunze, R.; Harney, S.C.; Breier, G.; Marti, H.H.; O'Connor, J.J. A role for prolyl hydroxylase domain proteins in hippocampal synaptic plasticity. Hippocampus 2013, 872, 861-872. [CrossRef] [PubMed]

46. Zhang, W.; Petrovic, J.M.; Callaghan, D.; Jones, A.; Cui, H.; Howlett, C.; Stanimirovic, D. Evidence that hypoxia-inducible factor-1 (HIF-1) mediates transcriptional activation of interleukin-1beta (IL-1 $\beta$ ) in astrocyte cultures. J. Neuroimmunol. 2006, 174, 63-73. [CrossRef] [PubMed]

47. Batti, L.; Taylor, C.T.; O'Connor, J.J. Hydroxylase inhibition reduces synaptic transmission and protects against a glutamate-induced ischemia in the CA1 region of the rat hippocampus. Neuroscience 2010, 167, 1014-1024. [CrossRef] [PubMed]

48. Wang, X.R.; Ma, Q.; Ding, A.S.; Zeng, B.X.; Wang, F.Z. Effects of intermittent hypoxia on long-term potentiation in hippocampal dentate gyrus of rat. Zhongguo Ying Yong Sheng Li Xue Za Zhi 2001, 17, 18-20. [PubMed] 
49. Payne, R.S.; Goldbart, A.; Gozal, D.; Schurr, A. Effect of intermittent hypoxia on long-term potentiation in rat hippocampal slices. Brain Res. 2004, 1029, 195-199. [CrossRef] [PubMed]

50. Xie, H.; Yung, W. Chronic intermittent hypoxia-induced deficits in synaptic plasticity and neurocognitive functions: A role for brain-derived neurotrophic factor. Acta Pharmacol. Sin. 2012, 33, 5-10. [CrossRef] [PubMed]

51. Domac, F.M.; Somay, G.; Misirli, H.; Erenoglu, N.Y. Tumor necrosis factor alpha serum levels and inflammatory response in acute ischemic stroke. Neurosciences 2007, 12, 25-30. [PubMed]

52. Viviani, B.; Bartesaghi, S.; Gardoni, F.; Vezzani, A.; Behrens, M.M.; Bartfai, T.; Binaglia, M.; Corsini, E.; Di Luca, M.; Galli, C.L.; Marinovich, M. Interleukin-1beta enhances NMDA receptor-mediated intracellular calcium increase through activation of the Src family of kinases. J. Neurosci. 2003, 23, 8692-8700. [PubMed]

53. Eltzschig, H.K.; Carmeliet, P. Hypoxia and inflammation. N. Engl. J. Med. 2011, 364, 656-665. [PubMed]

54. Stanimirovic, D.; Zhang, W.; Howlett, C.; Lemieux, P.; Smith, C. Inflammatory gene transcription in human astrocytes exposed to hypoxia: Roles of the nuclear factor-kappaB and autocrine stimulation. J. Neuroimmunol. 2001, 119, 365-376. [CrossRef]

55. Morgan, M.J.; Liu, Z.-G. Crosstalk of reactive oxygen species and NF-кB signaling. Cell Res. 2011, $21,103-115$. [CrossRef] [PubMed]

56. Saito, Y.; Nishio, K.; Ogawa, Y.; Kimata, J.; Kinumi, T.; Yoshida, Y.; Noguchi, N.; Niki, E. Turning point in apoptosis/necrosis induced by hydrogen peroxide. Free Radic. Res. 2006, 40, 619-630. [CrossRef] [PubMed]

57. Takeda, M.; Shirato, I.; Kobayashi, M.; Endou, H. Hydrogen peroxide induces necrosis, apoptosis, oncosis and apoptotic oncosis of mouse terminal proximal straight tubule cells. Nephron 1999, 81, 234-238. [CrossRef] [PubMed]

58. Smith, S.M.; Friedle, S.A.; Watters, J.J. Chronic intermittent hypoxia exerts CNS region-specific effects on rat microglial inflammatory and TLR4 gene expression. PLoS ONE 2013, 8, e81584. [CrossRef] [PubMed]

59. Udayabanu, M.; Kumaran, D.; Nair, R.U.; Srinivas, P.; Bhagat, N.; Aneja, R.; Katyal, A. Nitric oxide associated with iNOS expression inhibits acetylcholinesterase activity and induces memory impairment during acute hypobaric hypoxia. Brain Res. 2008, 1230, 138-149. [CrossRef] [PubMed]

60. Saha, R.N.; Pahan, K. Regulation of Inducible Nitric Oxide Synthase Gene in Glial Cells. Antioxid. Redox Signal. 2006, 8, 929-947. [CrossRef] [PubMed]

61. Yang, Q.; Wang, Y.; Feng, J.; Cao, J.; Chen, B. Intermittent hypoxia from obstructive sleep apnea may cause neuronal impairment and dysfunction in central nervous system: The potential roles played by microglia. Neuropsychiatr. Dis. Treat. 2013, 9, 1077-1086. [PubMed]

62. Ding, J.; Li, Q.Y.; Wang, X.; Sun, C.H.; Lu, C.Z.; Xiao, B.G. Fasudil protects hippocampal neurons against hypoxia-reoxygenation injury by suppressing microglial inflammatory responses in mice. J. Neurochem. 2010, 114, 1619-1629. [CrossRef] [PubMed]

63. Yeh, N.C.; Tien, K.J.; Yang, C.M.; Wang, J.J.; Weng, S.F. Increased risk of Parkinson's disease in patients with obstructive sleep apnea: A population-based, propensity score-matched, longitudinal follow-up study. Medicine 2016, 95, e2293. [CrossRef] [PubMed]

64. Baune, B.T.; Camara, M.-L.; Eyre, H.; Jawahar, C.; Anscomb, H.; Körner, H. Tumour necrosis factor-Alpha mediated mechanisms of cognitive dysfunction. Transl. Neurosci. 2012, 3, 263-277. [CrossRef]

65. Watters, O.; O'Connor, J.J. A role for tumor necrosis factor- $\alpha$ in ischemia and ischemic preconditioning. J. Neuroinflamm. 2011, 8, 1-8. [CrossRef] [PubMed]

66. Chen, G.; Goeddel, D.V. TNF-R1 signaling: A beautiful pathway. Science 2002, 296, 1634-1635. [CrossRef] [PubMed]

67. Glazner, G.W.; Mattson, M.P. Differential effects of BDNF, ADNF9, and TNF $\alpha$ on levels of NMDA receptor subunits, calcium homeostasis, and neuronal vulnerability to excitotoxicity. Exp. Neurol. 2000, 161, 442-452. [CrossRef] [PubMed]

68. Marchetti, L.; Klein, M.; Schlett, K.; Pfizenmaier, K.; Eisel, U.L. Tumor necrosis factor (TNF)-mediated neuroprotection against glutamate-induced excitotoxicity is enhanced by $N$-methyl-D-aspartate receptor activation. Essential role of a TNF receptor 2-mediated phosphatidylinositol 3-kinase-dependent NF-kappa B pathway. J. Biol. Chem. 2004, 279, 32869-32881. [CrossRef] [PubMed]

69. Veroni, C.; Gabriele, L.; Canini, I.; Castiello, L.; Coccia, E.; Remoli, M.E.; Columba-Cabezas, S.; Aricò, E.; Aloisi, F. Agresti, C. Activation of TNF receptor 2 in microglia promotes induction of anti-inflammatory pathways. Mol. Cell. Neurosci. 2010, 45, 234-244. [CrossRef] [PubMed] 
70. Belarbi, K.; Jopson, T.; Tweedie, D.; Arellano, C.; Luo, W.; Greig, N.H.; Rosi, S. TNF- $\alpha$ protein synthesis inhibitor restores neuronal function and reverses cognitive deficits induced by chronic neuroinflammation. J. Neuroinflamm. 2012, 9, 23. [CrossRef] [PubMed]

71. Marousi, S.; Antonacopoulou, A.; Kalofonos, H.; Papathanasopoulos, P.; Karakantza, M.; Ellul, J. Functional inflammatory genotypes in ischemic stroke: Could we use them to predict age of onset and long-term outcome? Stroke Res. Treat. 2011, 2011, 792923. [CrossRef] [PubMed]

72. Klein, B.D.; White, H.S.; Callahan, K.S. Cytokine and intracellular signaling regulation of tissue factor expression in astrocytes. Neurochem. Int. 2000, 36, 441-449. [CrossRef]

73. Tsoi, L.-M.; Wong, K.-Y.; Liu, Y.-M.; Ho, Y.-Y. Apoprotein E isoform-dependent expression and secretion of pro-inflammatory cytokines TNF-alpha and IL-6 in macrophages. Arch. Biochem. Biophys. 2007, 460, 33-40. [CrossRef] [PubMed]

74. Lull, M.E.; Block, M.L. Microglial activation and chronic neurodegeneration. Neurotherapeutics 2010, 7, 354-365. [CrossRef] [PubMed]

75. Barichello, T.; dos Santos, I.; Savi, G.D.; Simões, L.R.; Silvestre, T.; Comim, C.M.; Sachs, D.; Teixeira, M.M.; Teixeira, A.L.; Quevedo, J. TNF- $\alpha$, IL-1 $\beta$, IL-6, and cinc-1 levels in rat brain after meningitis induced by Streptococcus pneumoniae. J. Neuroimmunol. 2010, 221, 42-45. [CrossRef] [PubMed]

76. Liu, T.; Clark, R.K.; McDonnell, P.C.; Young, P.R.; White, R.F.; Barone, F.C.; Feuerstein, G.Z. Tumor necrosis factor-alpha expression in ischemic neurons. Stroke 1994, 25, 1481-1488. [CrossRef] [PubMed]

77. Batti, L.; O'Connor, J.J. Tumor necrosis factor-alpha impairs the recovery of synaptic transmission from hypoxia in rat hippocampal slices. J. Neuroimmunol. 2010, 218, 21-27. [CrossRef] [PubMed]

78. O'Connor, J.J. Targeting tumour necrosis factor- $\alpha$ in hypoxia and synaptic signaling. Ir. J. Med. Sci. 2013, 182, 157-162. [CrossRef] [PubMed]

79. Hindryckx, P.; De Vos, M.; Jacques, P.; Ferdinande, L.; Peeters, H.; Olievier, K.; Bogaert, S.; Brinkman, B.; Vandenabeele, P.; Elewaut, D. Hydroxylase inhibition abrogates TNF- $\alpha$-induced intestinal epithelial damage by hypoxia-inducible factor-1-dependent repression of FADD. J. Immunol. 2010, 185, 6306-6316. [CrossRef] [PubMed]

80. Rosenzweig, H.L.; Minami, M.; Lessov, N.S.; Coste, S.C.; Stevens, S.L.; Henshall, D.C.; Meller, R.; Simon, R.P.; Stenzel-Poore, M.P. Endotoxin preconditioning protects against the cytotoxic effects of TNF $\alpha$ after stroke: A novel role for TNFalpha in LPS-ischemic tolerance. J. Cereb Blood Flow Metab. 2007, 27, 1663-1674. [CrossRef] [PubMed]

81. Fan, H.; Cook, J.A. Molecular mechanisms of endotoxin tolerance. J. Endotoxin Res. 2004, 10, 71-84. [CrossRef] [PubMed]

82. Stetler, R.A.; Leak, R.K.; Gan, Y.; Li, P.; Zhang, F.; Hu, X.; Jing, Z.; Chen, J.; Zigmond, M.J.; Gao, Y. Preconditioning provides neuroprotection in models of CNS disease: Paradigms and clinical significance. Prog. Neurobiol. 2014, 114, 58-83. [CrossRef] [PubMed]

83. Bastide, M.; Gelé, P.; Pétrault, O.; Pu, Q.; Caliez, A.; Robin, E.; Deplanque, D.; Duriez, P.; Bordet, R. Delayed cerebrovascular protective effect of lipopolysaccharide in parallel to brain ischemic tolerance. J. Cereb. Blood Flow Metab. 2003, 23, 399-405. [CrossRef] [PubMed]

84. Karikó, K.; Weissman, D.; Welsh, F.A. Inhibition of toll-like receptor and cytokine signaling-A unifying theme in ischemic tolerance. J. Cereb. Blood Flow Metab. 2004, 24, 1288-1304. [CrossRef] [PubMed]

85. Lastres-Becker, I.; Cartmell, T.; Molina-Holgado, F. Endotoxin preconditioning protects neurones from in vitro ischemia: Role of endogenous IL-1beta and TNF-alpha. J. Neuroimmunol. 2006, 173, 108-116. [CrossRef] [PubMed]

86. Pickering, M.; O'Connor, J.J. Pro-inflammatory cytokines and their effects in the dentate gyrus. Prog. Brain Res. 2007, 163, 339-354. [PubMed]

87. Cumiskey, D.; Butler, M.P.; Moynagh, P.N.; O'Connor, J.J. Evidence for a role for the group I metabotropic glutamate receptor in the inhibitory effect of tumor necrosis factor-alpha on long-term potentiation. Brain Res. 2007, 1136, 13-19. [CrossRef] [PubMed]

88. Butler, M.P.; O'Connor, J.J.; Moynagh, P.N. Dissection of tumor-necrosis factor-alpha inhibition of long-term potentiation (LTP) reveals a p38 mitogen-activated protein kinase-dependent mechanism which maps to early-but not late-phase LTP. Neuroscience 2004, 124, 319-326. [CrossRef] [PubMed] 


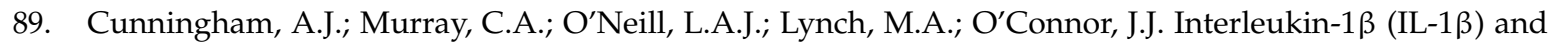
tumour necrosis factor (TNF) inhibit long-term potentiation in the rat dentate gyrus in vitro. Neurosci. Lett. 1996, 203, 17-20. [CrossRef]

90. Tancredi, V.; D'Arcangelo, G.; Grassi, F.; Tarroni, P.; Palmieri, G.; Santoni, A.; Eusebi, F. Tumor necrosis factor alters synaptic transmission in rat hippocampal slices. Neurosci. Lett. 1992, 146, 176-178. [CrossRef]

91. Curran, B.; Murray, H.; O'Connor, J.J. A role for c-jun n-terminal kinase in the inhibition of long-term potentiation by interleukin- $1 \beta$ and long-term depression in the rat dentate gyrus in vitro. Neuroscience 2003, 118, 347-357. [CrossRef]

92. Stellwagen, D.; Malenka, R.C. Synaptic scaling mediated by glial TNF-alpha. Nature 2006, 440, $1054-1059$. [CrossRef] [PubMed]

93. Beattie, E.C.; Stellwagen, D.; Morishita, W.; Bresnahan, J.C.; Ha, B.K.; Von Zastrow, M.; Beattie, M.S.; Malenka, R.C. Control of synaptic strength by glial TNFalpha. Science 2002, 295, 2282-2285. [CrossRef] [PubMed]

94. Stellwagen, D.; Beattie, E.C.; Seo, J.Y.; Malenka, R.C. Differential regulation of AMPA receptor and GABA receptor trafficking by tumor necrosis factor-alpha. J. Neurosci. 2005, 25, 3219-3228. [CrossRef] [PubMed]

95. Vesce, S.; Rossi, D.; Brambilla, L.; Volterra, A. Glutamate release from astrocytes in physiological conditions and in neurodegenerative disorders characterized by neuroinflammation. Int. Rev. Neurobiol. 2007, 82, 57-71. [PubMed]

96. Korn, T.; Magnus, T.; Jung, S. Autoantigen specific T cells inhibit glutamate uptake in astrocytes by decreasing expression of astrocytic glutamate transporter GLAST: A mechanism mediated by tumor necrosis factor-alpha. FASEB J. 2005, 19, 1878-1880. [CrossRef] [PubMed]

97. Boycott, H.E.; Wilkinson, J.A.; Boyle, J.P.; Pearson, H.A.; Peers, C. Differential involvement of TNF alpha in hypoxic suppression of astrocyte glutamate transporters. Glia 2008, 56, 998-1004. [CrossRef] [PubMed]

98. Carmen, J.; Rothstein, J.D.; Kerr, D.A. Tumor necrosis factor-alpha modulates glutamate transport in the CNS and is a critical determinant of outcome from viral encephalomyelitis. Brain Res. 2009, 1263, 143-154. [CrossRef] [PubMed]

99. He, P.; Liu, Q.; Wu, J.; Shen, Y. Genetic deletion of TNF receptor suppresses excitatory synaptic transmission via reducing AMPA receptor synaptic localization in cortical neurons. FASEB J. 2012, 26, 334-345. [CrossRef] [PubMed]

100. Santello, M.; Bezzi, P.; Volterra, A. TNF- $\alpha$ controls glutamatergic gliotransmission in the hippocampal dentate gyrus. Neuron 2011, 69, 988-1001. [CrossRef] [PubMed]

101. Arai, A.; Lynch, G. Factors regulating the magnitude of long-term potentiation induced by theta pattern stimulation. Brain Res. 1992, 598, 173-184. [CrossRef]

102. Wall, A.M.; Mukandala, G.; Nigel, H.; O'Connor, J.J. Tumor necrosis factor- $\alpha$ potentiates long-term potentiation in the rat dentate gyrus after acute hypoxia. J. Neurosci. Res. 2015, 93, 815-829. [CrossRef] [PubMed]

103. Culver, C.; Sundqvist, A.; Mudie, S.; Melvin, A.; Xirodimas, D.; Rocha, S. Mechanism of hypoxia-induced NF-kappaB. Mol. Cell. Biol. 2010, 30, 4901-4921. [CrossRef] [PubMed]

104. Pickering, M.; Cumiskey, D.; O'Connor, J.J. Actions of TNF- $\alpha$ on glutamatergic synaptic transmission in the central nervous system. Exp. Physiol. 2005, 90, 663-670. [CrossRef] [PubMed]

(C) 2016 by the authors; licensee MDPI, Basel, Switzerland. This article is an open access article distributed under the terms and conditions of the Creative Commons by Attribution (CC-BY) license (http://creativecommons.org/licenses/by/4.0/). 